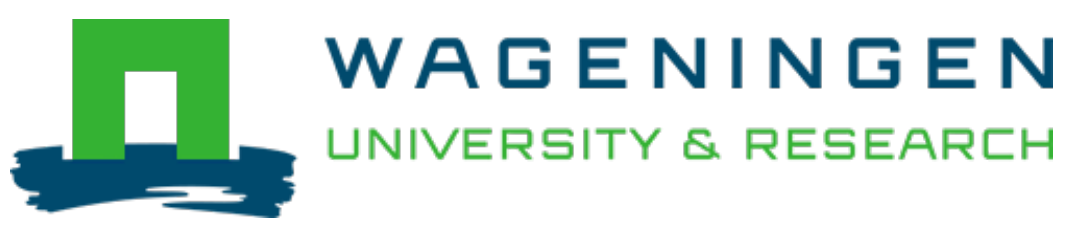

\title{
Preservation of blue-jack mackerel (Trachurus picturatus Bowdich) silage by chemical and fermentative acidification
}

\author{
Journal of Food Processing and Preservation \\ Enes Dapkevicius, M.L.N.; Nout, M.J.R.; Rombouts, F.M.; Houben, J.H. \\ https://doi.org/10.1111/j.1745-4549.2007.00142.x
}

This publication is made publicly available in the institutional repository of Wageningen University and Research, under the terms of article $25 \mathrm{fa}$ of the Dutch Copyright Act, also known as the Amendment Taverne. This has been done with explicit consent by the author.

Article 25 fa states that the author of a short scientific work funded either wholly or partially by Dutch public funds is entitled to make that work publicly available for no consideration following a reasonable period of time after the work was first published, provided that clear reference is made to the source of the first publication of the work.

This publication is distributed under The Association of Universities in the Netherlands (VSNU) 'Article $25 \mathrm{fa}$ implementation' project. In this project research outputs of researchers employed by Dutch Universities that comply with the legal requirements of Article $25 \mathrm{fa}$ of the Dutch Copyright Act are distributed online and free of cost or other barriers in institutional repositories. Research outputs are distributed six months after their first online publication in the original published version and with proper attribution to the source of the original publication.

You are permitted to download and use the publication for personal purposes. All rights remain with the author(s) and / or copyright owner(s) of this work. Any use of the publication or parts of it other than authorised under article $25 \mathrm{fa}$ of the Dutch Copyright act is prohibited. Wageningen University \& Research and the author(s) of this publication shall not be held responsible or liable for any damages resulting from your (re)use of this publication.

For questions regarding the public availability of this publication please contact openscience.library@wur.nl 


\title{
PRESERVATION OF BLUE-JACK MACKEREL (TRACHURUS PICTURATUS BOWDICH) SILAGE BY CHEMICAL AND FERMENTATIVE ACIDIFICATION
}

\author{
MARIA L.N. ENES DAPKEVICIUS ${ }^{1}$, M.J. ROBERT NOUT ${ }^{2,4}$, \\ FRANK M. ROMBOUTS ${ }^{2}$ and JACQUES H. HOUBEN ${ }^{3}$ \\ ${ }^{1}$ Center for Agricultural Technology Research (CITA-A) \\ Department of Agricultural Science \\ University of The Azores \\ Terra Chã, 9701-851 Angra do Heroísmo, Azores, Portugal \\ ${ }^{2}$ Laboratory of Food Microbiology \\ Wageningen University \\ PO Box 8129, Wageningen, EV 6700, the Netherlands \\ ${ }^{3}$ Utrecht University \\ IRAS, Public Health and Food Safety Division \\ PO Box 80175, 3508 TD Utrecht, the Netherlands
}

Accepted for Publication April 9, 2007

\begin{abstract}
We compared acidified and lactic acid fermented silage approaches for the preservation of blue-jack mackerel. Silages acidified with formic and propionic acids had stable $\mathrm{pH}(3.8)$ and low $(19 \mathrm{mg} / \mathrm{g} \mathrm{N})$ levels of volatile nitrogen compounds (total volatile basic nitrogen, TVBN), but relatively high $(82 \mathrm{~g} / 100 \mathrm{~g})$ final non-protein-nitrogen (NPN) values.

The silage was fermented with Lactobacillus plantarum LU853, a homofermentative lactic acid bacterium with a high growth $(0.51 / \mathrm{h})$ and acidification rate at $37 \mathrm{C}$ (optimum temperature), able to grow in the presence of $40 \mathrm{~g} / \mathrm{L}$ $\mathrm{NaCl}$ and to ferment sucrose and lactose. The silages at $37 \mathrm{C}$ reached safe $p H<4.5$ values within $48-72 h$, either $(F 2 a)$ or not $(F 0)$, in combination with $20 \mathrm{~g} / \mathrm{kg}$ salt addition; F2a acidified more rapidly, which may be an advantage for its microbiological stability. Proteolysis resulting in 53-59g $N P N / 100 \mathrm{~g} N$ was lower in fermented than in acidified silages; however, in fermented silages, the levels of TVBN were much higher $(50-80 \mathrm{mg}$ $T V B N / g N$ ) than generally considered acceptable.

${ }^{4}$ Corresponding author. TEL: +31-317-482834; FAX: +31-317-484978; EMAIL: rob.nout@wur.nl




\section{PRACTICAL APPLICATIONS}

Preservation of underutilized fish/fish waste by acidification would provide a sustainable means of preserving a valuable, increasingly scarce resource. Such fish silages may be used as a component of animal feeds, as a fertilizer or as a source for the extraction of bioactive compounds, such as enzymes that are suitable for gentle processing at low temperatures or bioactive peptides (e.g., gastrins, cholecystokinins and peptides with opioid-like activity). These compounds may be used for enhancing growth and disease resistance of animals, and possibly in the pharmacological industries. Fish silages may also be used as culture media components for the cultivation of microorganisms.

\section{INTRODUCTION}

In spite of its increasing scarcity, fish catch is not always fully utilized because of premature spoilage. In addition, fish processing generates by-products that require preservation. Transformation and preservation through silage has been considered (Lindgren and Pleje 1983) as the most suitable procedure for recycling wastes and by-products from the fish processing industry. Fish silages are mainly produced for animal feeds (Raa and Gildberg 1982), for human consumption (Mackie et al. 1971) and as plant fertilizers (Synnes and Opstad 1995). Silages are regarded as stable when their $\mathrm{pH}$ is below 4.5 (Lassen 1995b). In principle, acidification can be achieved by adding acids (here referred to as "acidified silage") or by fermentation with lactic acid bacteria (LAB) ("fermented silage"). Considerable deterioration can occur while the $\mathrm{pH}$ is still $>4.5$. Proteolysis can be a problem, particularly when it leads to excessive formation of volatile nitrogen compounds, offensive off-odors, undesirable formation of gas and decreased nutritional value (Raa and Gildberg 1982). The critical period during which the $\mathrm{pH}$ of the silages is above 4.5 must be kept as short as possible. According to Lindgren and Pleje (1983), the $\mathrm{pH}$ decrease to values below 4.5 must be completed within $48-72 \mathrm{~h}$ to ensure silage stability and safety.

Fish preservation by addition of acids has been described (Raa and Gildberg 1982); when using organic acids, a target $\mathrm{pH}$ of 3.5-4.0 for adequate preservation could be obtained using a mix of acetic $(20 \mathrm{~g} / \mathrm{kg}$ ), formic $(15 \mathrm{~g} / \mathrm{kg})$, propionic $(4 \mathrm{~g} / \mathrm{kg})$, benzoic $(4 \mathrm{~g} / \mathrm{kg})$ and sorbic $(1 \mathrm{~g} / \mathrm{kg})$ acids. Although acid addition was reported to result in stable silages, independent of temperature, they could still permit mold growth at their surface (Raa and Gildberg 1982). 
$\mathrm{LAB}$, in very small numbers, are part of the natural microflora of fish (Raa et al. 1983). However, inoculating the fish pastes intended for fish silage production with a suitable culture of LAB will greatly enhance the acidification. A starter LAB culture must be able to ferment the added carbohydrate(s) by the homofermentative pathway in order to produce as much lactic acid as possible while avoiding gas production (Mackie et al. 1971); it must have a high growth rate at the intended temperature range and compete with the fish native microflora (Adams et al. 1987). At the Azores, the ambient temperature range is 17-20C; from an energy-saving point of view, it would be of interest to preserve the fish at this temperature. Optimum temperatures for lactic acid fermentation of fish silage are 35-40C, and we used 37C as an optimum temperature in our comparative tests.

To avoid spoilage of the silages, the duration of the critical period until the $\mathrm{pH}$ decreases below 4.5 should be minimized by incubation at optimum temperature or by incorporation of additives that inhibit undesirable microorganisms. Gram-negative bacteria of the genera Pseudomonas and the Acinetobacter-Moraxella group predominate among the microflora of deteriorating fish (Jackson et al. 1997). Because these bacteria are sensitive to $\mathrm{NaCl}$, salt could be used to protect the silages during early stages of fermentation and to ensure their subsequent preservation. The buffering capacity of fish pastes is especially high within $\mathrm{pH}$ 5-6 (Adams et al. 1987). Therefore, considerable time (with chances of deterioration) may elapse before a safe $\mathrm{pH}<4.5$ has been achieved (Owens and Mendoza 1985). Decreasing the initial $\mathrm{pH}$ of the silages by adding organic acids could complement LAB action during this initial period. Combinations of $\mathrm{NaCl}$ and low initial $\mathrm{pH}$ could lead to stronger inhibition of undesirable microorganisms (Schabolt et al. 2001; Koutsoumanis et al. 2003). Under conditions of oxygen access, mold growth can occur on the silage surfaces, leading to deterioration and even to mycotoxin formation. Propionic acid has been used to control mold growth on the exposed surfaces of fish silages (Johnsen and Skrede 1981; Strom and Eggum 1981; Lindgren and Pleje 1983).

Blue-jack mackerel is abundant and fetches low prices in the Azores, resulting in occasional dumping of unused catch of this species in the municipal landfills. Whereas our focus was not on comparisons with other fish species, we aimed at comparing preservation options for blue-jack mackerel silage, including the above-mentioned approaches to shorten the critical acidification period and to protect silages against undesirable microorganisms, with additives. In addition to comparing acidified and fermented silages, we also assessed the effects of $\mathrm{pH}$ adjustments and of the addition of salt and propionic acid on the microbiological stability, proteolysis and physicochemical properties of fish silage. 


\section{MATERIALS AND METHODS}

\section{Strains}

Several Lactobacillus spp., isolated from naturally fermented foods and feeds, were tested for their potential applicability as silage inoculum. These included Lactobacillus plantarum LU849, LU850, LU855 and LU856 (isolated from grass silages [Bonestroo et al. 1992]); Lb. plantarum LU853, LU854 and $\mathrm{Lb}$. casei LU852 (isolated from tempe soak water ([Nout et al. 1987]); Lb. delbrückii CUC-I; and Lactobacillus sp. LPS-20 and LPCD-8 (isolated from olives). LU strains were provided by the Laboratory of Food Microbiology of Wageningen University, the Netherlands; the other strains were obtained from the Technical University of Lisbon, Portugal. The strains were maintained in de Man, Rogosa and Sharpe (MRS) agar (MRS broth with $15 \mathrm{~g} / \mathrm{L}$ added Bacto Agar; Pronadisa, 1056, Hispanlab, Madrid, Spain) as stab cultures, at $4 \mathrm{C}$. Overnight $(12-16 \mathrm{~h})$ cultures were obtained prior to use as silage starter, by subculturing three times in MRS broth (Merck 1066, Darmstadt, Germany).

\section{Properties of the Isolates}

Growth at 17 and $37 \mathrm{C}$, and growth in the presence of $40 \mathrm{~g} / \mathrm{L} \mathrm{NaCl}$ were monitored in MRS broth by measuring the optical density at $\lambda=620 \mathrm{~nm}$ with a blank of sterile MRS broth. Measurements were taken at 1-h intervals during the first $24 \mathrm{~h}$; the isolates incubated at $17 \mathrm{C}$ were measured during three consecutive days. The $\mathrm{pH}$ was measured directly in samples of the broth cultures (Nout et al. 1989). Ability to ferment sucrose and lactose was judged from the acidification in modified MRS in which glucose was replaced by these sugars, and chlorophenol red was added $(0.4 \mathrm{~g} / \mathrm{L})$ as $\mathrm{pH}$ indicator. All tests were performed in triplicate.

\section{Fish Silage}

Fresh blue-jack mackerel (average length, $38 \mathrm{~cm}$ ) (Trachurus picturatus Bowdich) was purchased at the local market in Angra do Heroísmo, Azores, Portugal, and was immediately used for silage preparation. Whole - not eviscerated - fish were cut into pieces and ground in a meat grinder through a 4-mm diameter die.

The variables under study were as follows: sucrose addition (10 and $12 \%) ; \mathrm{NaCl}$ addition (0, 2 and $4 \%$ ); addition of $3 \%$ formic acid $+0.75 \%$ propionic acid at time 0 ; and addition of $0.75 \%$ formic acid (added after completion of fermentation). The acidification treatments were carried out only on the fish silages with $12 \%$ added sucrose $+2 \%$ added $\mathrm{NaCl}$. 
TABLE 1.

COMPOSITION OF EXPERIMENTAL SILAGES OF BLUE-JACK MACKEREL (TRACHURUS PICTURATUS)

\begin{tabular}{llllllllll}
\hline Treatment & $\begin{array}{l}\text { GRF } \\
(\mathrm{kg})\end{array}$ & $\begin{array}{l}\text { Water } \\
(\mathrm{kg})\end{array}$ & $\begin{array}{l}\text { Sucrose } \\
(\mathrm{kg})\end{array}$ & $\begin{array}{l}\mathrm{NaCl} \\
(\mathrm{kg})\end{array}$ & $\begin{array}{l}\text { Formic } \\
\mathrm{acid} \\
(\mathrm{kg})\end{array}$ & $\begin{array}{l}\text { Propionic } \\
\mathrm{acid} \\
(\mathrm{kg})\end{array}$ & $\mathrm{HCl}$ & $\begin{array}{l}\text { Starter* } \\
(\mathrm{kg})\end{array}$ & $\begin{array}{l}\text { Initial } \\
\mathrm{pH}\end{array}$ \\
\hline A & 8.625 & 1.0 & - & - & 0.3 & 0.075 & - & - & 3.8 \\
F0 & 7.7 & 1.0 & 1.2 & - & - & - & - & 0.1 & 6.7 \\
F2a & 7.5 & 1.0 & 1.2 & 0.2 & - & - & - & 0.1 & 6.6 \\
F2b & 7.5 & 1.0 & 1.2 & 0.2 & - & - & tr $\dagger$ & 0.1 & 5.1 \\
F2c & 7.425 & 1.0 & 1.2 & 0.2 & - & $0.075 \ddagger$ & - & 0.1 & 6.5 \\
F4 & 7.3 & 1.0 & 1.2 & 0.4 & - & - & - & 0.1 & 6.6 \\
\hline
\end{tabular}

* Lactobacillus plantarum LU 853 culture grown $12-16 \mathrm{~h}$ at $30 \mathrm{C}$, achieving initial inoculation level of $10^{6} \mathrm{cfu} / \mathrm{g}$ silage.

$\dagger$ Trace level to adjust $\mathrm{pH}$ to $5.1 ; \ddagger$ added after completion of fermentation.

A, acidified silage; F0, fermented silage, with numbers indicating salt levels, with a: standard, b: pH adjusted to 5.1 and c: added propionic acid; GRF, ground raw fish.

Table 1 shows the composition of the different types of silages. Tapwater was added in order to obtain a pasty consistency. Added ingredients (sucrose, $\mathrm{NaCl}$, formic acid and propionic acid as required) were dissolved or mixed in the water prior to preparation of the fish paste. The level of sucrose $(120 \mathrm{~g} / \mathrm{kg})$ was quite high but effective, and was initially based on studies using molasses (Dong et al. 1993). Cane molasses were added (Dong et al. 1993) to fish for ensiling at levels of $40-300 \mathrm{~g} / \mathrm{kg}$. These authors did not state the sugar concentration in the molasses they used. The average sucrose content of molasses is about $470 \mathrm{~g} / \mathrm{kg}$, so sucrose was present at $20-140 \mathrm{~g} / \mathrm{kg}$. We found (Dapkevicius et al. 1998), however, that $200 \mathrm{~g} / \mathrm{kg}$ molasses addition (corresponding to approximately $94 \mathrm{~g} / \mathrm{kg}$ sucrose) did not lead to a $\mathrm{pH}$ below 4.5 within the required $48 \mathrm{~h}$. For this reason, a higher sucrose concentration was applied in the present work. For acidified silage (A), we simplified the mix of organic acids (Raa and Gildberg 1982), as mentioned in the Introduction, to include only $30 \mathrm{~g} / \mathrm{kg}$ formic acid and $7.3 \mathrm{~g} / \mathrm{kg}$ propionic acid, aiming at a silage $\mathrm{pH}$ of 3.8 .

For each treatment, a batch of $10 \mathrm{~kg}$ was prepared by manual paddlemixing during $15 \mathrm{~min}$, and was distributed into jars $(300 \mathrm{~g} / 500-\mathrm{mL}$ glass screw-capped jar), so that four jars per treatment per day were available. Thus, 28 jars (four jars for each sampling day) were prepared per treatment. Any remaining mixture was discarded.

To each jar of silage for fermentation, $10 \mathrm{~g} / \mathrm{kg}$ of 12- to 16-h-old MRS broth cultures of $L b$. plantarum LU 853 was added, giving initial counts of $10^{6}-10^{7} \mathrm{cfu} / \mathrm{g}$. After inoculation, the pastes were thoroughly mixed and the jars 
were sealed to exclude air. Incubation was carried out in an incubator (37C) and at room temperature $(17 \pm 1 \mathrm{C})$.

\section{Microbiological Analysis}

At each sampling time (days 0, 1, 2, 3, 7, 14 and 21), four jars of each treatment were opened and sampled for $\mathrm{pH}$ measurement and microbiological analysis. After thorough mixing by spatula, $20 \mathrm{~g}$ of ensiled paste was aseptically collected. Appropriate decimal dilutions were prepared in sterile peptone physiological saline $(1 \mathrm{~g} / \mathrm{L}$ bacteriological peptone and $9 \mathrm{~g} / \mathrm{L} \mathrm{NaCl}$ in demineralized water). The LAB were enumerated on MRS agar (CM 361, Oxoid, Hampshire, England) pour plates containing $1 \mathrm{~g} / \mathrm{L}$ natamycin (Delvocid, DSM, Delft, the Netherlands) after incubation for 5 days at $30 \mathrm{C}$ in an anaerobic jar (Anaerocult A, Merck KGaA). Coliform bacteria were plated on Violet Red Bile Agar (0012-01-5, Difco, Detroit, MI) pour plates with an overlay of the same medium, incubated at $37 \mathrm{C}$ for $24 \mathrm{~h}$. Yeasts and molds were enumerated on Potato Dextrose Agar spread plates (CM 139, Oxoid, Basingstoke, U.K.) acidified to $\mathrm{pH} 3.5$ with a $100 \mathrm{~g} / \mathrm{L}$ tartaric acid solution, after incubation at $25 \mathrm{C}$ for 5 days. Heat-resistant aerobic bacterial spores were enumerated on pour plates of Plate Count agar (0479-01-1, Difco) after inactivation of the vegetative cells at $80 \mathrm{C}$ during $5 \mathrm{~min}$. All analyses were performed in quadruplicate.

\section{Chemical Analysis}

For the determination of non-protein nitrogen (NPN), $25 \mathrm{~g}$ of silage was homogenized for $5 \mathrm{~min}$ with $150 \mathrm{~mL}$ of $7 \%$ trichloroacetic acid and was filtered through Whatman No. 1 paper (Batista et al. 1987); the nitrogen content of the filtrate was determined by a micro-Kjeldahl procedure (AOAC 1990). Total volatile basic nitrogen (TVBN) was determined by the Conway microdiffusion method (Anon 1988). All analyses were performed in quadruplicate.

\section{Water-binding Capacity/Moisture-releasing Properties of Silages (Silage Moisture Release, SMR)}

Fifteen-gram samples of silage were thoroughly mixed and centrifuged at $25,000 \times \mathrm{g}$ for $30 \mathrm{~min}$ at $12 \mathrm{C}$ in a refrigerated centrifuge (DAMON, B-20A, Damon/IEC Division, Needham, MA). The supernatant was discarded and the sediment was weighed. The SMR (g/100 g) was calculated as 100 - (weight of sediment/weight of the initial sample $) \times 100$.

\section{Statistical Analysis}

Rates of growth and acidification were obtained by fitting equations by linear regression (least squares method) to the growth and $\mathrm{pH}$ data obtained 
during screening tests of the LAB cultures. Separation of the means was performed by the Duncan test (Snedecor and Cochran 1980).

\section{RESULTS AND DISCUSSION}

\section{Screening of LAB Cultures}

All strains had been selected on the basis of their homofermentative metabolism. Table 2 lists the strains according to increasing growth rate. The rates of growth and acidification were not necessarily correlated. For practical applications, the abilities to ferment sucrose as well as lactose, and the ability to grow in the presence of salt and at a broad range of temperatures were considered to be important selection criteria. On the basis of its versatility, $L b$. plantarum LU853 was selected for experimental fish silages.

\section{Effect of Silage Treatments on Acidification and Microbiological Composition}

Tables 3 and 4 show the results of experiments with ground fish preserved by acid addition (A) and ground fish that was fermented (F) under experimental conditions. The obvious characteristic of the acidified silage (A) was its low $\mathrm{pH}(3.6-3.8)$ throughout the experiment, which was adjusted to the recommendations made elsewhere (Raa and Gildberg 1982), and which was lower than the $\mathrm{pH}$ range (4.0-4.5) obtained in successfully fermented silages (Lassen 1995a; Ahmed and Mahendrakar 1996). Table 3 shows that this treatment is microbiologically stable.

Of the fermented ground fish silages, the control formulation F0 was tested at both 17 and 37C. The data in Tables 3 and 4 indicate that at 37C, a significant growth of LAB with concomitant disappearance of coliforms and yeasts and molds took place, resulting in a lowering of the $\mathrm{pH}$ to $<4.5$ within 2 days. In contrast, at $17 \mathrm{C}$, the $\mathrm{LAB}$ growth was much slower and it took 7 days to lower the $\mathrm{pH}$ to 4.5 (data not shown). This slower acidification allowed the proliferation of Gram-negative bacteria such as coliforms, as well as yeasts and molds. We therefore considered the fermentation at $17 \mathrm{C}$ inadequate, and other formulations were tested at $37 \mathrm{C}$ only.

Addition of $20 \mathrm{~g} / \mathrm{kg}$ salt (F2a) did not significantly affect the LAB growth, but the $\mathrm{pH}$ decreased more rapidly than in F0. This combination of salt and rapid acidification reduced the numbers of coliform bacteria, as well as yeasts and molds, effectively. When the silage process was started by adjusting the $\mathrm{pH}$ to 5.1 (F2b), the microbial growth was strongly restricted; the LAB remained at inoculum level, whereas levels of coliform bacteria and yeasts and molds were similar as in acidified silage (A). The addition of propionic acid 


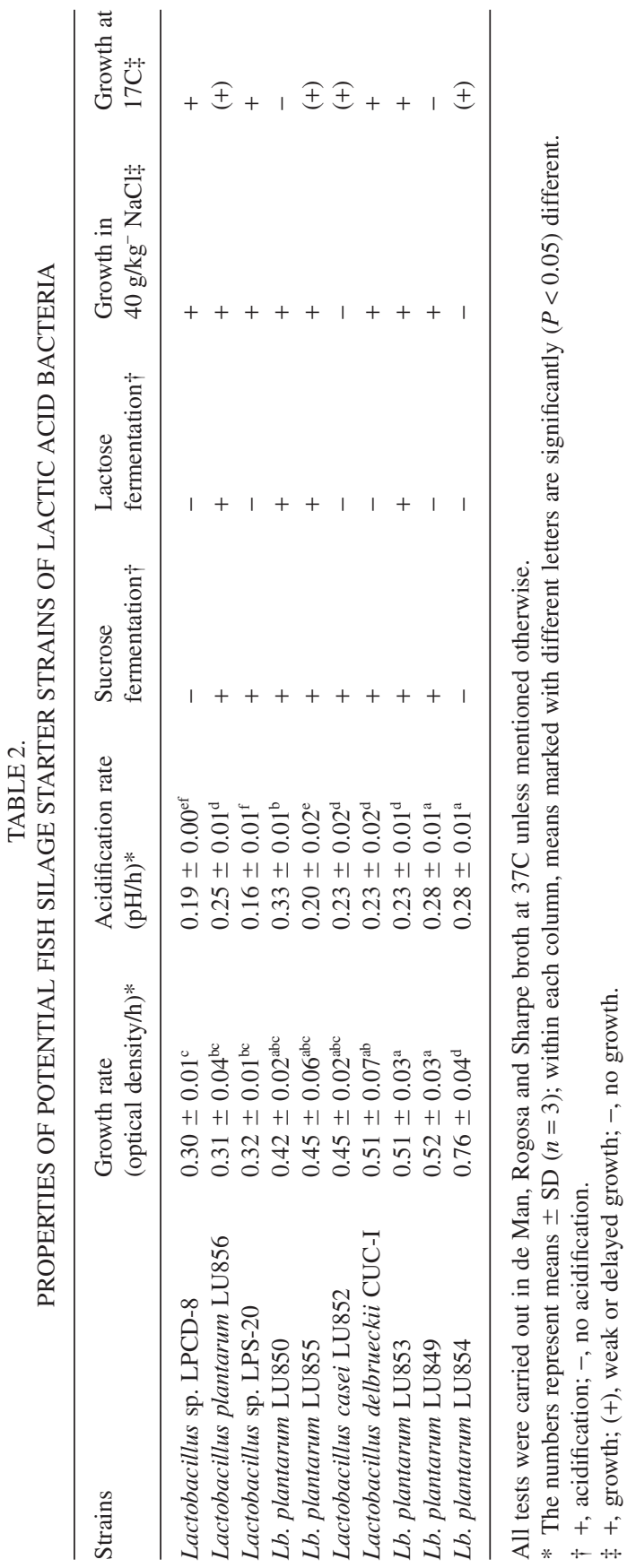


TABLE 3.

MICROBIOLOGICAL CHANGES DURING EXPERIMENTAL SILAGES AT 37C OF BLUE-JACK MACKEREL WITH LACTOBACILLUS PLANTARUM LU853

\begin{tabular}{|c|c|c|c|c|c|c|c|}
\hline & \multirow{2}{*}{$\begin{array}{l}\text { Period } \\
\text { (d) }\end{array}$} & \multicolumn{6}{|c|}{ Treatment } \\
\hline & & A & F0 & $\mathrm{F} 2 \mathrm{a}$ & $\mathrm{F} 2 \mathrm{~b}$ & $\mathrm{~F} 2 \mathrm{c}$ & $\mathrm{F} 4$ \\
\hline \multirow{6}{*}{$\begin{array}{l}\text { LAB } \\
\text { (log cfu/g) }\end{array}$} & 0 & $<1.85$ & $5.4 \pm 0.0^{\mathrm{a}}$ & $5.2 \pm 0.0^{\mathrm{b}}$ & $5.3 \pm 0.4^{\mathrm{ab}}$ & $5.3 \pm 0.1^{\mathrm{ab}}$ & $5.4 \pm 0.1^{\mathrm{a}}$ \\
\hline & 1 & $<1.85$ & $6.6 \pm 0.1^{\mathrm{a}}$ & $6.7 \pm 0.0^{\mathrm{a}}$ & $5.8 \pm 0.4^{\mathrm{b}}$ & $6.2 \pm 0.1^{\mathrm{b}}$ & $5.9 \pm 0.2^{\mathrm{b}}$ \\
\hline & 3 & $<1.85$ & $9.6 \pm 0.0^{\mathrm{a}}$ & $8.0 \pm 0.0^{\mathrm{b}}$ & $5.9 \pm 0.3^{c}$ & $6.1 \pm 0.1^{\mathrm{c}}$ & $8.6 \pm 0.0^{\mathrm{d}}$ \\
\hline & 7 & $<1.85$ & $10.2 \pm 0.7^{\mathrm{a}}$ & $9.9 \pm 0.7^{\mathrm{a}}$ & $5.3 \pm 0.0^{\mathrm{b}}$ & $5.7 \pm 0.1^{\mathrm{c}}$ & $8.7 \pm 0.1^{\mathrm{d}}$ \\
\hline & 14 & $<1.85$ & $9.0 \pm 0.0^{\mathrm{a}}$ & $7.6 \pm 0.0^{\mathrm{b}}$ & $5.0 \pm 0.1^{\mathrm{c}}$ & $5.0 \pm 0.1^{\mathrm{c}}$ & $8.3 \pm 0.0^{\mathrm{d}}$ \\
\hline & 21 & $<1.85$ & $8.6 \pm 0.0^{\mathrm{a}}$ & $7.0 \pm 0.0^{\mathrm{b}}$ & $4.7 \pm 0.1^{c}$ & $4.9 \pm 0.2^{\mathrm{c}}$ & $8.1 \pm 0.0^{\mathrm{d}}$ \\
\hline \multirow{6}{*}{$\begin{array}{l}\text { CB } \\
(\log \mathrm{cfu} / \mathrm{g})\end{array}$} & 0 & $<1.85$ & $<1.85$ & $<1.85$ & $<1.85$ & $<1.85$ & $<1.85$ \\
\hline & 1 & $<1.85$ & $4.6 \pm 0.0^{\mathrm{a}}$ & $3.5 \pm 0.0^{\mathrm{b}}$ & $<1.85$ & $<1.85$ & $<1.85$ \\
\hline & 3 & $<1.85$ & $<1.85$ & $<1.85$ & $<1.85$ & $<1.85$ & $5.8 \pm 0.0$ \\
\hline & 7 & $<1.85$ & $<1.85$ & $<1.85$ & $<1.85$ & $<1.85$ & $5.8 \pm 0.1$ \\
\hline & 14 & $<1.85$ & $<1.85$ & $<1.85$ & $<1.85$ & $<1.85$ & $5.4 \pm 0.1$ \\
\hline & 21 & $<1.85$ & $<1.85$ & $<1.85$ & $<1.85$ & $<1.85$ & $5.4 \pm 0.2$ \\
\hline \multirow{6}{*}{$\begin{array}{l}\text { YM } \\
\text { (log cfu/g) }\end{array}$} & 0 & $<2.85$ & $<2.85$ & $<2.85$ & $<2.85$ & $3.2 \pm 0.1$ & $<2.85$ \\
\hline & 1 & $<2.85$ & $<2.85$ & $<2.85$ & $<2.85$ & $3.2 \pm 0.1$ & $<2.85$ \\
\hline & 3 & $<2.85$ & $<2.85$ & $<2.85$ & $<2.85$ & $<2.85$ & $6.8 \pm 0.7$ \\
\hline & 7 & $<2.85$ & $<2.85$ & $<2.85$ & $<2.85$ & $<2.85$ & $6.9 \pm 0.3$ \\
\hline & 14 & $<2.85$ & $<2.85$ & $<2.85$ & $<2.85$ & $3.8 \pm 0.4^{\mathrm{a}}$ & $7.9 \pm 0.6^{b}$ \\
\hline & 21 & $<2.85$ & $<2.85$ & $<2.85$ & $<2.85$ & $3.5 \pm 0.2^{\mathrm{a}}$ & $7.7 \pm 0.9^{b}$ \\
\hline
\end{tabular}

Means \pm SD ( $n=$ four jars). In the same line, values with different superscripts are significantly $(P<0.05)$ different.

A, acidified silage; F0, fermented silage, with numbers indicating salt levels, with a: standard, b: $\mathrm{pH}$ adjusted to 5.1 and c: added propionic acid; LAB, lactic acid bacteria; $\mathrm{CB}$, coliform bacteria; YM, yeasts and molds; $\mathrm{Nd}$, not determined.

(F2c) had no advantages compared to F2a; in contrast, the levels of yeasts and molds slightly increased in this silage. Finally, the addition of $40 \mathrm{~g} / \mathrm{kg}$ salt (F4) did not offer any advantages compared to F2a or F0, as acidification was slower and the high levels of coliform bacteria and yeasts and molds indicate microbiological instability. This indicates that the occurring coliform bacteria are not very sensitive to salt, and thus, their disappearance in F2a must have resulted mainly from acidification. No aerobic spores were detected in any of the silages, not even in those that did not reach the $\mathrm{pH}$ values $<4.5$, low enough for preservation.

\section{Effect of Silage Treatments on Nitrogenous Compounds}

Levels of NPN shown in Table 4 result from production (proteolysis or autolysis [Raa and Gildberg 1982]) and consumption (microbial assimilation). In silage $\mathrm{A}$, in which microbiological activity is negligible, we therefore 
TABLE 4.

PHYSICOCHEMICAL CHANGES DURING EXPERIMENTAL SILAGES AT 37C OF BLUE-JACK MACKEREL WITH LACTOBACILLUS PLANTARUM LU853

\begin{tabular}{|c|c|c|c|c|c|c|c|}
\hline & \multirow{2}{*}{$\begin{array}{l}\text { Period } \\
\text { (d) }\end{array}$} & \multicolumn{6}{|l|}{ Treatment } \\
\hline & & A & F0 & $\mathrm{F} 2 \mathrm{a}$ & $\mathrm{F} 2 \mathrm{~b}$ & $\mathrm{~F} 2 \mathrm{c}$ & $\mathrm{F} 4$ \\
\hline \multirow[t]{7}{*}{$\mathrm{pH}$} & 0 & 3.8 & 6.7 & 6.6 & 5.1 & 6.5 & 6.6 \\
\hline & 1 & 3.6 & 5.4 & 4.8 & 4.8 & 5.0 & 6.0 \\
\hline & 2 & 3.8 & 4.4 & 3.8 & 3.7 & 4.2 & 4.6 \\
\hline & 3 & 3.7 & 3.9 & 3.6 & 3.7 & 3.7 & 4.0 \\
\hline & 7 & 3.8 & 3.9 & 3.9 & 3.8 & 4.0 & 4.0 \\
\hline & 14 & 3.8 & 4.1 & 3.9 & 3.8 & 4.0 & 4.0 \\
\hline & 21 & 3.8 & 4.1 & 3.9 & 4.0 & 4.0 & 4.1 \\
\hline \multirow{7}{*}{$\begin{array}{l}\text { NPN } \\
(g / 100 \mathrm{~g} \mathrm{~N})\end{array}$} & 0 & $24 \pm 1^{\mathrm{a}}$ & $12 \pm 1^{\mathrm{bc}}$ & $13 \pm 0^{\mathrm{b}}$ & $17 \pm 1^{\mathrm{d}}$ & $17 \pm 0^{\mathrm{d}}$ & $11 \pm 0^{\mathrm{c}}$ \\
\hline & 1 & $\mathrm{Nd}$ & $\mathrm{Nd}$ & $\mathrm{Nd}$ & $\mathrm{Nd}$ & $\mathrm{Nd}$ & $\mathrm{Nd}$ \\
\hline & 2 & $\mathrm{Nd}$ & $\mathrm{Nd}$ & $\mathrm{Nd}$ & $\mathrm{Nd}$ & $\mathrm{Nd}$ & $\mathrm{Nd}$ \\
\hline & 3 & $45 \pm 5^{\mathrm{a}}$ & $58 \pm 2^{\mathrm{b}}$ & $67 \pm 2^{c}$ & $68 \pm 2^{c}$ & $63 \pm 6^{c}$ & $47 \pm 1^{\mathrm{a}}$ \\
\hline & 7 & $69 \pm 1^{\mathrm{a}}$ & $62 \pm 1^{b}$ & $62 \pm 2^{b}$ & $67 \pm 4^{b}$ & $78 \pm 2^{c}$ & $53 \pm 1^{\mathrm{d}}$ \\
\hline & 14 & $\mathrm{Nd}$ & $\mathrm{Nd}$ & $\mathrm{Nd}$ & $\mathrm{Nd}$ & $\mathrm{Nd}$ & $\mathrm{Nd}$ \\
\hline & 21 & $83 \pm 5^{a}$ & $60 \pm 4^{b}$ & $59 \pm 1^{b}$ & $70 \pm 1^{\mathrm{c}}$ & $71 \pm 3^{c}$ & $46 \pm 5^{d}$ \\
\hline \multirow{7}{*}{$\begin{array}{l}\text { TVBN } \\
(\mathrm{mg} / \mathrm{g} \mathrm{N})\end{array}$} & 0 & $14 \pm 1^{\mathrm{a}}$ & $9 \pm 1^{b}$ & $9 \pm 1^{b}$ & $10 \pm 1^{b}$ & $12 \pm 1^{\mathrm{a}}$ & $8 \pm 1^{b}$ \\
\hline & 1 & $\mathrm{Nd}$ & $\mathrm{Nd}$ & $\mathrm{Nd}$ & $\mathrm{Nd}$ & $\mathrm{Nd}$ & $\mathrm{Nd}$ \\
\hline & 2 & $\mathrm{Nd}$ & $\mathrm{Nd}$ & $\mathrm{Nd}$ & $\mathrm{Nd}$ & $\mathrm{Nd}$ & $\mathrm{Nd}$ \\
\hline & 3 & $12 \pm 0^{\mathrm{a}}$ & $56 \pm 3^{b}$ & $50 \pm 2^{c}$ & $46 \pm 2^{c}$ & $72 \pm 5^{\mathrm{d}}$ & $47 \pm 2^{c}$ \\
\hline & 7 & $15 \pm 2^{\mathrm{a}}$ & $58 \pm 4^{b}$ & $51 \pm 1^{\mathrm{c}}$ & $51 \pm 3^{b c}$ & $80 \pm 5^{d}$ & $53 \pm 1^{\mathrm{bc}}$ \\
\hline & 14 & $16 \pm 1^{\mathrm{a}}$ & $62 \pm 0^{\mathrm{b}}$ & $52 \pm 2^{\text {ce }}$ & $51 \pm 1^{\mathrm{c}}$ & $75 \pm 7^{d}$ & $56 \pm 2^{\mathrm{e}}$ \\
\hline & 21 & $18 \pm 2^{\mathrm{a}}$ & $61 \pm 2^{b}$ & $53 \pm 1^{\mathrm{c}}$ & $54 \pm 2^{c}$ & $73 \pm 2^{d}$ & $53 \pm 5^{c}$ \\
\hline \multirow{7}{*}{$\begin{array}{l}\text { SMR } \\
(\mathrm{g} / 100 \mathrm{~g})\end{array}$} & 0 & $49.9 \pm 0.4^{\mathrm{a}}$ & $21.7 \pm 0.9^{b}$ & $0.1 \pm 0.0^{c}$ & $60.4 \pm 0.3^{d}$ & $0.1 \pm 0.0^{\mathrm{c}}$ & $0.0 \pm 0.0^{\mathrm{e}}$ \\
\hline & 1 & $\mathrm{Nd}$ & $\mathrm{Nd}$ & $\mathrm{Nd}$ & $\mathrm{Nd}$ & $\mathrm{Nd}$ & $\mathrm{Nd}$ \\
\hline & 2 & $\mathrm{Nd}$ & $\mathrm{Nd}$ & $\mathrm{Nd}$ & $\mathrm{Nd}$ & $\mathrm{Nd}$ & $\mathrm{Nd}$ \\
\hline & 3 & $58.6 \pm 0.3^{\mathrm{a}}$ & $65.2 \pm 0.9^{b}$ & $62.6 \pm 0.8^{c}$ & $77.0 \pm 0.4^{\mathrm{d}}$ & $74.1 \pm 0.8^{\mathrm{e}}$ & $58.8 \pm 0.9^{\mathrm{a}}$ \\
\hline & 7 & $62.8 \pm 0.4^{\mathrm{a}}$ & $65.1 \pm 0.6^{\mathrm{b}}$ & $62.4 \pm 0.9^{\mathrm{a}}$ & $76.7 \pm 0.3^{\mathrm{c}}$ & $72.6 \pm 0.9^{d}$ & $60.7 \pm 0.7^{\mathrm{e}}$ \\
\hline & 14 & $68.7 \pm 0.7^{a}$ & $65.5 \pm 0.9^{b}$ & $62.5 \pm 0.3^{\mathrm{c}}$ & $77.5 \pm 0.4^{\mathrm{d}}$ & $74.4 \pm 1.2^{\mathrm{e}}$ & $60.4 \pm 0.7^{\mathrm{f}}$ \\
\hline & 21 & $71.4 \pm 0.5^{\mathrm{a}}$ & $66.2 \pm 0.8^{\mathrm{b}}$ & $63.9 \pm 0.7^{\mathrm{c}}$ & $76.8 \pm 0.3^{\mathrm{d}}$ & $74.6 \pm 0.5^{\mathrm{e}}$ & $60.2 \pm 0.8^{f}$ \\
\hline
\end{tabular}

Means $\pm \mathrm{SD}(n=$ four jars). In the same line, values with different superscripts are significantly $(P<0.05)$ different.

A, acidified silage; F0, fermented silage, with numbers indicating salt levels, with a: standard, b: $\mathrm{pH}$ adjusted to 5.1 and c: added propionic acid; NPN, non-protein nitrogen; TVBN, total volatile basic nitrogen; SMR, silage moisture release; $\mathrm{Nd}$, not determined.

assume that consumption of NPN is very low. Apparently, proteolytic activity from ground fish released approximately $80 \mathrm{~g} \mathrm{NPN} / 100 \mathrm{~g} \mathrm{~N}$; this indicates that $80 \%$ of crude protein is degraded into peptides and smaller compounds. In the fermented silages, NPN levels were lower than in silage A. This indicates that the microflora does not increase the extent of proteolysis, but rather assimilates some NPN. 
Considering the formation of TVBN, an interesting difference between the acidified (A) and fermented silages can be observed. Whereas in silage A the level of TVBN remains stable at $15-19 \mathrm{mg} / \mathrm{g} \mathrm{N}$ (Table 4), the fermented silages show significantly higher levels ranging from $52-75 \mathrm{mg}$ TVBN. Although no TVBN limit for acceptability of Trachurus has been established (Gimenez et al. 2002), acceptable levels for whole and filleted fish range from 25-40 mg/100 g flesh (Gimenez et al. 2002; Chytiri et al. 2004), which corresponds to $15-25 \mathrm{mg} / \mathrm{g} \mathrm{N}$ in fatty fish such as mackerel. Whereas the acidified silage complies with this level, the fermented silages clearly exceed this, which we relate to the effect of microbial activity (Chytiri et al. 2004). All the same, the fermented silages were free of objectionable odors.

\section{Effect of Silage Treatments on Water-binding Properties}

The water-binding properties affect the consistency of the silage and the amounts of moisture released. In Figs. 1 and 2, the available data of SMR were plotted against their corresponding $\mathrm{pH}$ and NPN levels, respectively. As already known, $\mathrm{pH}$ is a major factor determining the water-binding properties of muscle proteins, hence directly affecting the SMR of fresh silages (from our data, a correlation coefficient -0.919 was obtained). Once proteins gradually break down, NPN values will increase and SMR levels will rise (as illustrated in Fig. 2). In addition, the small range (50-80) of SMR levels at a relatively large range (20-80) of NPN values indicates that other additional factors have

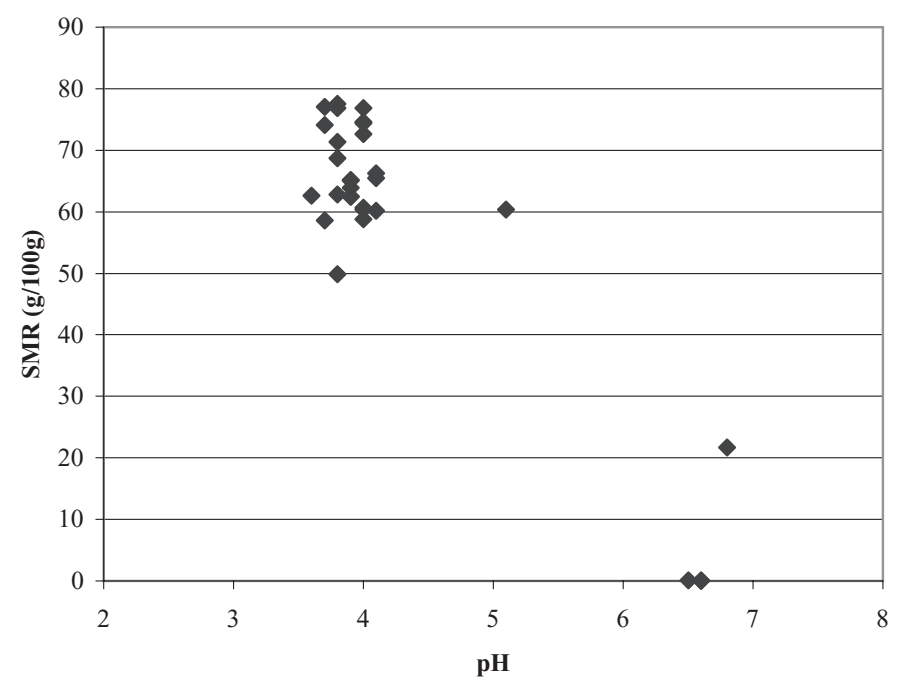

FIG. 1. PLOT OF pH AGAINST SILAGE MOISTURE RELEASE (SMR) (30-DATA POINTS) 


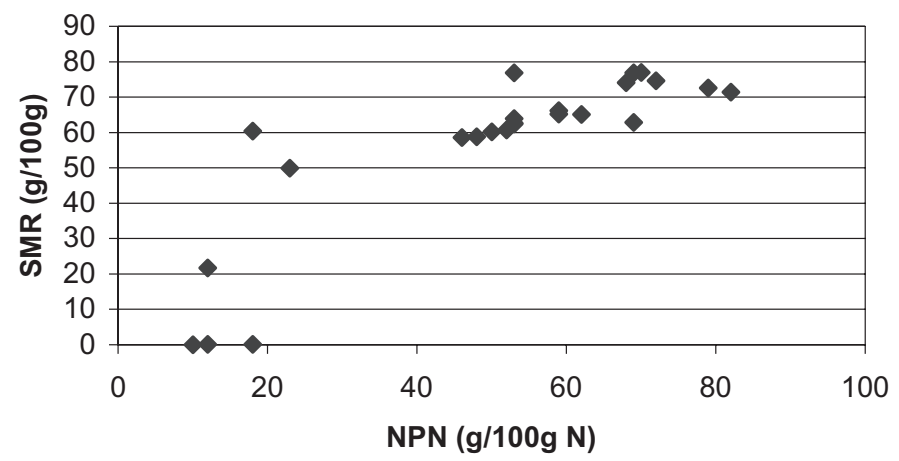

FIG. 2. PLOT OF NON-PROTEIN NITROGEN (NPN) AGAINST SILAGE MOISTURE RELEASE (SMR) (24-DATA POINTS)

a contributing effect. One of these factors is very likely the salt content, as it has been observed elsewhere (Wheaton and Lawson 1985; Lin and Park 1998) that salt at the levels applied here increases the water-binding properties of fish muscle.

\section{CONCLUSIONS}

Considering the criteria for stable, high-quality fish silage, it can be concluded that fermentation at $17 \mathrm{C}$ is unsuitable because of slow acidification; this implies that at "ambient" temperatures of the Azores (approximately 17-20C), the addition of acids will be required to shorten the critical period. Other unsuitable options (fermentations studied at 37C) were the addition of $40 \mathrm{~g} / \mathrm{kg}$ salt (F4) and the combination $20 \mathrm{~g} / \mathrm{kg}$ salt + propionate (F2c) because of the resulting microbiological instability. Rapid acidification and microbiologically stable silages were obtained by fermentation with $\mathrm{Lb}$. plantarum LU853, either (F2a) or not (F0) in combination with $20 \mathrm{~g} / \mathrm{kg}$ salt addition; F2a acidified more rapidly, which may be an advantage for its microbiological stability. Proteolysis resulting in NPN was similar in all silages; however, in acidified silages, the levels of TVBN were significantly lower. The final choice of silage-making method would therefore depend on the incubation temperature and on the importance given to the minor drawbacks attached to each of the scenarios, namely, the environmental impact of adding acids (silage A), the environmental impact of adding salt, and the generation of higher TVBN (silage F2b) or of slightly less rapid acidification, and generating higher TVBN (silage F0). For practical purposes, we expect that acidification, such as in silage $A$, will be the most feasible option. 


\section{ACKNOWLEDGMENTS}

This work was funded by EC grants ERB 4001GT 94/0050 (FLAIR Programme).

\section{REFERENCES}

ADAMS, M.R., COOKE, R.D. and TWIDDY, D.R. 1987. Fermentation parameters involved in the production of lactic acid preserved fishglucose substrates. Int. J. Food Sci. Technol. 22, 105-114.

AHMED, J. and MAHENDRAKAR, N.S. 1996. Chemical and microbiological changes in fish viscera during fermentation ensiling at different temperatures. Bioresour. Technol. 59, 45-46.

ANONYMOUS. 1988. Pescado. Determinação do teor de azoto básico volátil (A.B.V.T.). Método de Conway. Norma Portuguesa NP2930, Instituto Português de Qualidade, Lisbon, Portugal.

AOAC. 1990. Official Methods of Analysis, 15th Ed., Association of Official Analytical Chemists, Washington, DC.

BATISTA, I., MENDES, R. and NUNES, M.C. 1987. Ensilados ácidos e biológicos: preparação e estudo das alterações químicas ocorridas durante a armazenagem. In Textos das Comunicações do Seminário sobre Aquacultura, ICBAS/Associação Portuguesa de Recursos Hídricos, April 9-11, Oporto, Portugal.

BONESTROO, M.H., KUSTERS, B.J., DE WIT, J.C. and ROMBOUTS, F.M. 1992. Glucose and sucrose fermenting capacity of homofermentative lactic acid bacteria used as starters in fermented salads. Int. J. Food Microbiol. 15, 365-376.

CHYTIRI, S., CHOULIARA, I., SAVVAIDIS, I.N. and KONTOMINAS, M.G. 2004. Microbiological, chemical and sensory assessment of iced whole and filleted aquacultured rainbow trout. Food Microbiol. 21, 157165.

DAPKEVICIUS, M.L.N.E., BATISTA, I., NOUT, M.J.R., ROMBOUTS, F.M. and HOUBEN, J.H. 1998. Lipid and protein changes during the ensilage of blue whiting (Micromesistius poutassou Risso) by acid and biological methods. Food Chem. 63, 97-102.

DONG, F.M., FAIRGRIEVE, W.T., SKONBERG, D.I. and RASCO, B.A. 1993. Preparation and nutrient analysis of lactic acid bacterial ensiled salmon viscera. Aquaculture Res. 109, 351-366.

GIMENEZ, B., RONCALES, P. and BELTRAN, J.A. 2002. Modified atmosphere packaging of filleted rainbow trout. J. Sci. Food Agric. 82, 11541159 . 
JACKSON, T.C., ACUFF, G.R. and DICKSON, J.S. 1997. Meat, poultry and seafood. In Food Microbiology. Fundamentals and Frontiers, (M.P. Doyle, L.R. Beuchat and T.J. Montville, eds.) pp. 83-100, ASM Press, Washington, DC.

JOHNSEN, F. and SKREDE, A. 1981. Evaluation of fish viscera silage as a feed resource. Acta Agric. Scand. 31, 22-28.

KOUTSOUMANIS, K.P., KENDALL, P.A. and SOFOS, J.N. 2003. Effect of food processing-related stresses on acid tolerance of Listeria monocytogenes. Appl. Environ. Microbiol. 69, 7514-7516.

LASSEN, T.M. 1995a. Biological quality of fermented fish offal and chicken by-products. Agric. Sci. Finland 4, 27-33.

LASSEN, T.M. 1995b. Evaluation of conditions for fermentation of fish offal. Agric. Sci. Finland 4, 11-17.

LIN, T.M. and PARK, J.W. 1998. Solubility of salmon myosin as affected by conformational changes at various ionic strengths and $\mathrm{pH}$. J. Food Sci. 63, 215-218.

LINDGREN, S. and PLEJE, M. 1983. Silage fermentation of fish or fish waste products with lactic acid bacteria. J. Sci. Food Agric. 34, 10571067.

MACKIE, I.M., HARDY, R. and HOBBS, G. 1971. Fermented Fish Products. FAO Fisheries Reports, No. 100, Food and Agriculture Organization of the United Nations, Rome, Italy.

NOUT, M.J.R., DE DREU, M.A., ZUURBIER, A.M. and BONANTS-VAN LAARHOVEN, T.M.G. 1987. Ecology of controlled soyabean acidification for tempe manufacture. Food Microbiol. 4, 165-172.

NOUT, M.J.R., ROMBOUTS, F.M. and HAVELAAR, A. 1989. Effect of accelerated natural lactic fermentation of infant food ingredients on some pathogenic micro-organisms. Int. J. Food Microbiol. 8, 351-361.

OWENS, J.D. and MENDOZA, L.S. 1985. Enzymatically hydrolised and bacterially fermented fishery products. J. Food Technol. 20, 237-293.

RAA, J. and GILDBERG, A. 1982. Fish silage: A review. CRC Crit. Rev. Food Sci. Nutr. 16, 383-419.

RAA, J., GILDBERG, A. and STROM, T. 1983. Valorizing Waste for Feeds and Food, (D.A. Ledward, A.J. Taylor and R.A. Lawrie, eds.) pp. 117132, Butterworths, London, U.K.

SCHABOLT, C., ROSS, T. and MCMEEKIN, T.A. 2001. Differentiation of the effects of lethal $\mathrm{pH}$ and water activity: Food safety implications. Lett. Appl. Microbiol. 32, 99-102.

SNEDECOR, G.W. and COCHRAN, W.G. 1980. Statistical Methods, 7th Ed., Iowa State University Press, Ames, IA.

STROM, T. and EGGUM, B.O. 1981. Nutritional value of fish viscera silage. J. Sci. Food Agric. 32, 115-120. 
SYNNES, O.M. and OPSTAD, S. 1995. Effect of fish silage on the yield and chemical composition of Italian ryegrass (Lollium multiflorum Lam.). Acta Agric. Scand. B Soil Plant Sci. 45, 68-72.

WHEATON, F.W. and LAWSON, T.B. 1985. Other preservation methods. In Processing Aquatic Food Products, (F.W. Wheaton and T.B. Lawson, eds.) pp. 274-275, John Wiley \& Sons, New York, NY. 